\title{
Psychomotor Learning and the Achievement of Physical and Motor Development of Kindergarten Students during the COVID-19 Pandemic
}

\author{
Yudanto Yudanto ${ }^{1},{ }^{*}$ Sujarwo Sujarwo ${ }^{1}$, R. Sumardianta ${ }^{1}$, Ridho Gata Wijaya ${ }^{1}$ \\ ${ }^{1}$ Faculty of Sport Sciences, Universitas Negeri Yogyakarta, Yogyakarta, Indonesia \\ ${ }^{*}$ Corresponding author.Email: vudanto@uny.ac.id
}

\begin{abstract}
The Covid-19 pandemic has given a huge impact in the education world including the early childhood education level. In this level of education, the learning process is done to encourage the development students' motoric. Psychomotor learning includes activities which focus on gross and fine motion. The aim of this research is to determine the implementation of psychomotor learning and the achievement of psychomotor development in kindergarten during Covid-19 pandemic. This study is a descriptive quantitative research. The subjects of this research are 66 kindergarten teachers from 57 kindergartens and 958 students of level B kindergarten. The research instrument used in this study is an open and closed questionnaire. The open questionnaire contains questions of the psychomotor learning conducted by their teacher. Meanwhile, the closed questionnaire includes the questions about the implementation and the online learning media used by the teacher in the psychomotor learning. Observation sheet is used to record the observation results of the kindergarten students' activities and their gross and fine motor development. The data analysis used in this research is the descriptive-quantitative technique in the form of percentage. The research results are the psychomotor learning in kindergarten done in 4 (four) districts in Klaten Regency: Jogonalan District, South Klaten District, Kalikotes District and Wedi District. In general, everything was done properly with more than $78.8 \%$ of the learning process was done online. The most widely used learning media is WhatsApp Group which is used by $95.5 \%$ or 63 teachers of the total subject. $83.1 \%$ or 54 teachers in total use assignments as the psychomotor learning method. The achievement of gross and fine motor development can be categorized as Developing as Expected (Berkembang Sesuai Harapan) and Developing Very Well (Berkembang Sangat Baik) for more than $70 \%$.
\end{abstract}

Keywords: psychomotor learning, motor development, kindergarten students, Covid-19 pandemic

\section{INTRODUCTION}

COVID-19 pandemic has changed the world order and gave such extreme impact and alteration in every aspect including health, economy, social-culture and also education. To prevent the spread of COVID-19, Nadiem Anwar Makarim, the Minister of Education and Culture issued a Circular Letter Number 4 of 2020 (Surat Edaran Nomor 4 Tahun 2020) about the Implementation of Education during Emergency Period of Coronavirus Disease (Covid-19). One of the main points is related to the implementation of study from home. As for the learning activities and assignments can be varied from one student to the other depends on their interest and condition including the gap of learning facilities which they can access from home (Circular Letter Number 4 of 2020).
Early childhood education is an education intended for children in the early childhood. According to Law Number 20 of 2003 about National Education System Act 1, Section 14 states that Early Childhood Education is a development effort intended to children since they were born until the age of six which is done through giving education stimulation to help them grow and develop physically and spiritually in order to be ready to enter the next education level. Kindergarten is one of early childhood formal education forms which organizes education program for children at the age of four to six years old. Based on the kindergarten curriculum, it is mentioned three goals that are need to be achieved: (1) building the foundation for developing students' potencies in order to be a person who believes in God the Almighty and possesses noble character, noble personality, healthy, knowledgeable, capable, critical, creative, innovative, independent, confident, and becomes a democratic and 
responsible citizen, (2) developing the students' spiritual intelligence, intellectual, emotional, kinesthetic and social skill during their golden age of growth in their play environment which is educative and fun, and (3) helping students develop varieties of potencies, both mentally and physically, including the values of religious and moral, socio-emotional, independence, cognitive and language, and physical/motor in order to be ready to enter elementary school [7].

The content of Early Childhood curriculum is varieties of program consisting of: (1) moral and religious value development programs which include the embodiment of a learning atmosphere for good behavior development that sources from religious and moral values and also social life in the context of play, (2) psychomotor development programs which include the embodiment of a learning atmosphere to develop kinesthetic maturity in the context of play, (3) cognitive development programs which include the embodiment of a learning atmosphere to develop thought process maturity in the context of play, (4) language development programs which include the embodiment of a learning atmosphere to develop language maturity in the context of play, (5) socioemotional development programs which include the embodiment of a learning atmosphere to develop sensitivity, behavior, social skills and emotional maturity in the context of play, (6) art development programs which include the embodiment of a learning atmosphere to encourage exploration, expression and appreciation towards art in the context of play.

The learning implementation is aimed to achieve those six development aspects. Many of these learning processes are obstructed during Covid-19 pandemic more specifically the physical and motor learning. The activity restriction implemented by the government through lockdown policy to suppress the spread of Coronavirus forced the learning activities to be done at home. The children's activities at home with their morning routine of going to school need some adaptation process to change into new learning activities which put forward parent's role in conducting the learning process. Previously, the learning activities are fully handled by teachers at school but now after the Covid-19 struck, parents need to be able to act as the teacher and school for their children [6]. The learning activities for children during lockdown are varied and this is caused by the fact that each child has their own activities when they are at home.

The implementation of the learning activities in kindergarten during pandemic is the base of this research. The aim of this research is to determine the varieties of learning method used to teach psychomotor learning in kindergarten during Covid-19 pandemic. Moreover, the use of online learning media is able to create alteration of the learning system in kindergarten schools in which it is not yet known the impact towards the achievement of the students' psychomotor development. Therefore, this research is also aimed to find out the psychomotor development achievement of kindergarten students during online learning throughout Covid-19 pandemic.

\section{METHODS}

\subsection{Participants}

The population is generalization area which includes: object/subject that has certain characteristics set by the researchers to be studied and then drawn the conclusion. The subject of this research is 66 kindergarten teachers in 57 different kindergarten and 958 level B kindergarten students in Klaten Regency.

\subsection{Desain}

This is descriptive quantitative research. The instrument used in this research is open and closed questionnaire. The open questionnaire contains questions related to psychomotor learning implemented by the teachers. Meanwhile, the closed questionnaire includes questions about the implementation and the online learning media use by the teachers in psychomotor learning. Observation sheet is used to record the scoring results after observing the activities of gross and fine motor development of kindergarten students.

\subsection{Data Analysis}

Data analysis is a technique used to solve a problem from the research results. The data analysis technique used is this research is descriptive quantitative in which the data is calculated and presented using numbers and then described. The techniques used in processing the data are: (1) Checking the instruments such as observation sheet, documentation guide, etc. (2) Giving the score in the observation sheet according to the children's gross and fine motor skill which can be categorized into Not Developing (BB), Starting to Develop (MB), Developing As Expected (BSH), and Developing Very Well (BSB). (3) Presenting the visual data in the form of bar chart or histogram. To find out the total category of gross and fine motor development whether it is in the category of $\mathrm{BB}, \mathrm{MB}, \mathrm{BSH}$, and $\mathrm{BSB}$ can use the percentage formula from Anas Sudijono (2010).

$$
\begin{aligned}
& \mathrm{P}=\mathrm{f} / \mathrm{N} \times 100 \% \\
& \text { Notes: } \\
& \mathrm{P}=\text { Percentage. } \\
& \mathrm{f}=\text { Frequency } \\
& \mathrm{N}=\text { Number of children }
\end{aligned}
$$




\section{RESULTS}

\subsection{Psychomotor Learning during Pandemic}

According to the results of closed questionnaire related to the implementation of psychomotor learning using online learning media during Covid-19 pandemic as shown in Graph 4.1, it can be seen that $78.8 \%$ or 52 teachers answered "Yes", $21.2 \%$ or 14 teachers answered "Sometimes" and $1.15 \%$ or 1 teacher answered "No" in conducting online learning during Covid-19 pandemic.

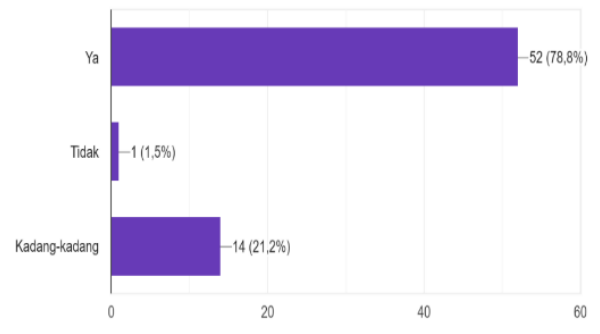

Graph 1. Teachers conduct online learning

The media used by the kindergarten teachers in conducting online learning involve: $6.1 \%$ or 4 teachers use google meet, $10.6 \%$ or 7 teachers use zoom meeting, $95.5 \%$ or 63 teachers use WhatsApp Group and $66.7 \%$ or 44 teachers use home visit.

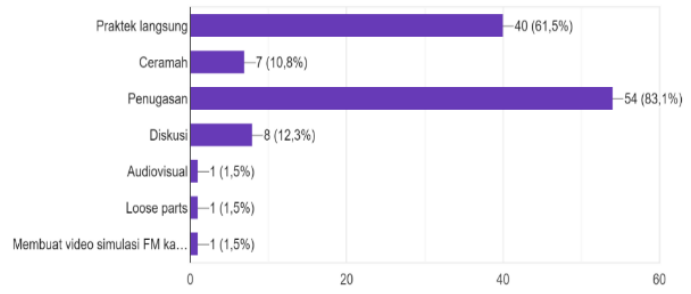

Graph 2. Online learning method for psychomotor learning

The results related to online learning media in psychomotor learning are $61.5 \%$ or 40 teachers use direct teaching method, $10.8 \%$ or 7 teachers use lecture method, $83.1 \%$ or 54 teachers use assignment method, $12.3 \%$ or 8 teachers use discussion method, $1.5 \%$ or 1 teacher use audiovisual method and $1.5 \%$ or 1 teacher uses making simulation video method.

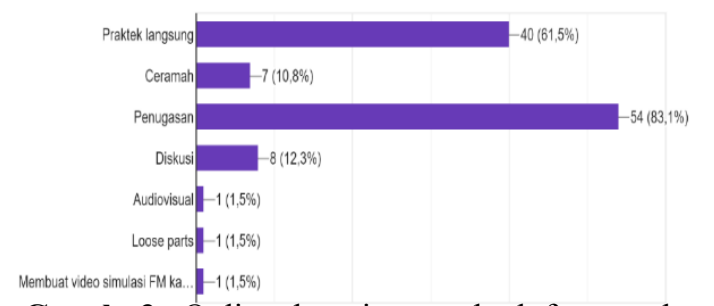

Graph 3. Online learning method for psychomotor learning

\subsection{Gross and Fine Motor Skill}

The achievement of gross and fine motor skill is shown in the following table:

Table 1. Gross and fine motor skill

\begin{tabular}{|l|l|l|l|l|l|l|}
\hline No & \multicolumn{1}{|c|}{ Motor Skill } & BB & MB & BSH & BSB & Total \\
\hline 1 & $\begin{array}{l}\text { Spinning and swinging } \\
\text { skill }\end{array}$ & 29 & 132 & 471 & 326 & 958 \\
\hline 2 & Hoop playing skill & 34 & 168 & 443 & 313 & 958 \\
\hline 3 & $\begin{array}{l}\text { Various creeping and } \\
\text { crawling skills }\end{array}$ & 19 & 109 & 529 & 301 & 958 \\
\hline 4 & $\begin{array}{l}\text { The skill of rolling the } \\
\text { ball on the ground/floor } \\
\text { using one/two hands }\end{array}$ & 14 & 114 & 523 & 274 & 958 \\
\hline 5 & $\begin{array}{l}\text { Throwing/catching a ball } \\
\text { skill }\end{array}$ & 22 & 172 & 490 & 274 & 958 \\
\hline 6 & $\begin{array}{l}\text { Free drawing skill using } \\
\text { various media }\end{array}$ & 30 & 179 & 514 & 225 & 958 \\
\hline 7 & $\begin{array}{l}\text { The skill of copying } \\
\text { center line, slanted, flat } \\
\text { curve and circle }\end{array}$ & 11 & 98 & 487 & 362 & 958 \\
\hline 8 & $\begin{array}{l}\text { The skill of coloring } \\
\text { simple shape drawing } \\
\text { neatly }\end{array}$ & 12 & 127 & 494 & 314 & 958 \\
\hline 9 & $\begin{array}{l}\text { The skill of cutting } \\
\text { shape/pattern using } \\
\text { various media }\end{array}$ & 15 & 167 & 489 & 287 & 958 \\
\hline 10 & $\begin{array}{l}\text { The skill of making a } \\
\text { drawing using mosaic }\end{array}$ & 20 & 178 & 449 & 261 & 958 \\
\hline
\end{tabular}

Source: Closed Questionnaire Data, 2021

\section{DISCUSSION}

\subsection{Psychomotor Learning}

Based on the results from the closed questionnaire data related to the implementation of psychomotor learning using online learning media during Covid-19 pandemic as shown in Graph 1, it can be seen that $78.8 \%$ or 52 teachers answered "Yes", $21.2 \%$ or 14 teachers answered "Sometimes" and $1.15 \%$ or 1 teacher answered "No" in conducting online learning during Covid-19 pandemic. It shows that most of the kindergarten teachers in four (4) districts have conducted online learning even though there are still teachers who conduct the online learning occasionally and very few who has never done the online learning. However, the fast development of technology makes remote learning so much easier. Therefore, the chance of the teachers in implementing the online learning is bigger and it is expected that the learning process can be effective and optimal although it is not done face to face so the aim of education in facilitating the children's development process can be achieved [4].

During the implementation of remote learning, so many learning media which are able to accommodate the learning needs. Therefore, teachers need to be able to adapt to the technology that is growing fast because 
using various media, (5) The skill of making a drawing using mosaic. From the total of 958 kindergarten students, it shows that more than $70 \%$ of the students can be categorized as Developing as Expected (BSH) and Developing Very Well (BSB). Motoric Development is related to the children's skill to do something that requires their physical organ such as walking, running, moving their arms or hands, moving their fingers or their eyes [9]. A good physical and motor skill in a child is proven to make children's healthier and make them stronger as they grow older [15]. Children who have a good physical development will also possess a good cognitive and emotional development [1]. Meanwhile, the achievement of a good motor development is also proven to have a positive impact towards the children's future academic achievement [13]. Children's motor skill can also develop well if they received sufficient support from their surrounding both inside and outside the classroom [3].

\section{CONCLUSION}

Psychomotor learning in kindergarten schools in 4 (four) districts in Klaten Regency, involves: Jogonalan District, South Klaten District, Kalikotes District and Wedi District. In general, everything was done properly with more than $78.8 \%$ of the learning process was done online. The most widely used learning media is WhatsApp Group which is used by $95.5 \%$ or 63 teachers of the total subject. The psychomotor learning using assignment method is $83.1 \%$ or 54 teachers in total. The achievement of the children's gross and fine motor skill can be categorized as Developing as Expected (BSH) and Developing Very Well (BSB) with the total of more than $70 \%$. ademic researches that have been conducted reveal that cognitive and physical development in early childhood stage submits to the influence of the children's environment [12]. Therefore, with the support of stimulation from the teachers, it is expected it can maximize the development of children's psychomotor skill though conducted during Covid-19 pandemic.

\subsection{Gross and Fine Motor Skill Development}

The observation of gross motor skill involves: (1) spinning and swinging skill, (2) hoop playing skill, (3) various creeping and crawling skills, (4) the skill of rolling the ball on the ground/floor using one/two hands, (5) throwing/catching a ball skill. From the total of 958 kindergarten students, more than $70 \%$ of the students are categorized as Developing as Expected (BSH) and Developing Very Well (BSB). Whereas the observation of motor skill development includes: (1) Free drawing skill using various media, (2) The skill of copying center line, slanted, flat curve and circle, (3) The skill of coloring simple shape drawing neatly, (4) The skill of cutting shape/pattern

\section{REFERENCES}

[1] Bidzan-Bluma, I., \& Lipowska, M. Physical Activity and Cognitive Functioning of, 2018.

[2] Children: A Systematic Review. International Journal of Environmental Research and Public Health, 15(4), 1-13, http:// doi: 10.3390/ijerph15040800.

[3] Cameron, C. E., Cottone, E. A., Murrah, W. M., \& Grissmer, Performance and Academic Achievement? Child Development Perspectives, 10(2), 93-98. (2016), https://doi.org/10.1111/cdep.12168 COVID-19 Crisis. Journal of Educational Technology Systems, 49(1), 5-22. (2020). https://doi.org/10.1177/0047239520934018.

[5] Dubbert, M.P.. "Physical activity and exercise: Recent advances and Current Challenges". Journal of Consulting and Clinical Psychology, (2002) 70 (3): 526-536.

[6] Kemdiknas. Kurikulum Taman Kanak-kanak. (Pedoman Pengembangan Program Pembelajaran di Taman Kanakkanak. Jakarta: Kemdiknas Dirjen Manajemen Pendidikan Dasar dan Menengah, Direktorat Pembinaan Taman Kanakkanak dan Sekolah Dasar. 2010. D. W..How Are Motor Skills Linked to Children's School

[4] Dhawan, S. Online Learning: A Panacea in the Time of 
[7] Khadilkar, H., Ganu, T., \& Seetharam, D. P. Optimising Lockdown Policies for Epidemic Control using Reinforcement Learning. (2020), http://arxiv.org/abs/2003.14093

[8] Kim, J. Learning and Teaching Online During Covid-19: Experiences of Student Teachers in an Early Childhood Education Practicum. International Journal of Early Childhood, 52(2), 145-158. (2020), https://doi.org/10.1007/s13158-020-00272-6

[9] Noor, M.. Psikologi Perkembangan PAUD. Tangerang: CV. Loka Aksara, 2019

[10] Permendikbud. Kerangka Dasar dan Struktur Kurikulum PAUD. Jakarta: Kemendikbud, 2014.

[11] Sigmundsson, H., \& Haga, M. Motor competence is associated with physical fitness in four- to six-year-old preschool children. European Early Childhood Education Research Journal, 24 (3), 477-488. (2016), https://doi.org/10.10

[12] Sudijono, A. Pengantar Statistik Pendidikan. Jakarta: PT. Raja Grafindo Persada, 2010.

[13] Stephani, M. R., Wibowo, R., \& Sumarno, G.. Early Childhood Motor Development, 2019.

[14] Descriptive study in moslem kindergarten school. Advances in Health Sciences Research, 11, 243-245, https://doi.org/10.2991/icsshpe-18.2019.69.

[15] Utesch, T., \& et al. The Relationship Between Motor Competence and Physical Fitness from Early Childhood to Early Adulthood: A Meta-Analysis. Sports Medicine , 1-11, (2019). http:// doi.org/10.1007/s40279-019-01068-y. 